\title{
A Scoring System Approach for the Parasite Predictive Assessment of Fish Lots: A Proof of Concept with Anisakids
}

\author{
María Llarena-Reino, ${ }^{1, \star}$ Elvira Abollo, ${ }^{2}$ and Santiago Pascual ${ }^{1}$
}

\begin{abstract}
A total of 982 individuals distributed in 11 lots belonging to 10 fish species from three Atlantic FAO fishing areas were sampled and examined to detect the presence of anisakid larvae in fish muscle. After hazard identification by genetic sequencing and exposure assessment by anatomic extent and demographic characterization of infection, all data were fitted for each fish species to a new proposed scoring schema of parasite prediction. In the absence of a criterion standard method for inspection and precise definition of the quantum satis for parasites in contaminated fish lots, the inspection rating scheme called SADE (Site of infection, Assurance of quality, Demography, Epidemiology) may help fish industries to precisely handle and to evaluate the likely outcome of infected fish lots after being diagnosed. For this purpose, a supporting flow diagram for decision was defined and suggested. This new performance assessment tool has the aim of staging fish lots, thus helping in planning manufacture, commercial, and research decisions during self-management programs. This novel scoring system provides an improved inspection format by implementing the occurrence stratification for parasites to guide Hazard Analysis and Critical Control Points (HACCP) programs for the uniform exchange of information among fish industries, administration and researchers, thus facilitating standardization and communication. In the future, this scoring version could be validated (in terms of classification and wording) for similar overall predictive purposes in other muscular parasites infecting seafood products.
\end{abstract}

\section{Introduction}

S INCE THE MID-20 ${ }^{\mathrm{TH}}$ CENTURY, scientific evidence has confirmed the presence of L3 anisakid larvae in a high and rising number of fish species of commercial interest around the world (Smith and Wootten, 1979; McClelland et al., 1985; Adams et al., 1997; Abollo et al., 2001; Rello et al., 2009). The presence of this parasite causes clinical infections and sometimes produces panzootic fish diseases. Anisakid parasites represent the target tip of a "dirty list" of parasites found in seafood during veterinary inspections, with increasing present records in the Rapid Alert System for Food and Feed System. The economic losses and public health concern caused by the visual impact of both alive and dead anisakid worms decrease the commercial value of fishes (Vidacek et al., 2009). The recognized effects on human health of these emergent zoonoses (causing symptoms ranging from gastrointestinal disorders and allergic diseases in consumers to occupational asthma in fish-farming workers) (Smith and Wootten, 1978; Dick et al., 1991; Audicana et al., 2002; Plessis et al., 2004; Nieuwenhuizen et al., 2006; Chen et al., 2008; Vidacek et al., 2009) were recently recognized by the Panel on Biological Hazards of the European Food Safety Authority (EFSA, 2010).

Most anisakid larvae are found in the viscera, mesentery, and gonads of the fish (Vidacek et al., 2009), and in a lower amount in the flesh (Wharton et al., 1999; Llarena-Reino et al., 2012). The number of muscular anisakids depends basically on the ecological niche of fish species (Holst et al., 1993; Stromnes and Andersen, 1998). It has been noted that there is some postmortem migration of the larvae from the viscera cavity into flesh (Smith, 1984), although it is not clear when, under what conditions, and in which fish species this occurs (EFSA, 2010).

Currently, invasive fish inspection methods are considered "better" or "truer" because they allow direct examination of

\footnotetext{
${ }^{1}$ Ecobiomar, Instituto de Investigaciones Marinas de Vigo, Consejo Superior de Investigaciones Científicas (CSIC), Bouzas-Vigo, Spain.

${ }^{2}$ Centro Tecnológico Del Mar (Fundación CETMAR), Bouzas-Vigo, Spain.

*Current address: Centro de Estudos do Ambiente e do Mar (CESAM) \& Departamento de Biologia, Universidade de Aveiro, Campus de Santiago, Aveiro, Portugal.
} 
flesh parasites and their spread in the edible part of fish, in contrast to nondestructive methods, which in the case of whole fish are clearly limited by the fact that the information is obtained by making indirect observations at parasites in the gut (Commission Regulation (EC) No. 2074/2005), resulting in biased estimations with no statistical confidence (LlarenaReino et al., 2012). Several methods have been developed and used for detection, diagnosis, and identification of parasites in fish, from the oldest ones such as visual inspection (Hartmann and Klaus, 1988), light microscopy (Rijpstra et al., 1988), or candling (Wold et al., 2001; Butt et al., 2004), until some revised and recently updated ones such as the pepsin digestion protocol (Lysne et al., 1995; Lunestad, 2003; Thien et al., 2007; Thu et al., 2007; Llarena-Reino et al., 2013). These methods are being applied by fishery operators or laboratories. Recent techniques including ultraviolet illumination (Adams et al., 1999; Levsen et al., 2005; Marty, 2008), ultrasound (Hafsteinsson et al., 1989; Nilsen et al., 2008), X-rays and conductivity (Nilsen et al., 2008), electromagnetism (Choudhury and Bublitz, 1994), magnetometry (Jenks et al., 1996), immunological techniques (Xu et al., 2010; Rodríguez-Mahillo et al., 2010), polymerase chain reaction (PCR)-based (Zhu et al., 2002; Abe et al., 2005; Pontes et al., 2005), real-time PCR (Herrero et al., 2010; Fang et al., 2011), phage display (López et al., 2011), real-time fluorescence resonance energy transfer (Monis et al., 2005; Intapan et al., 2008), or imaging spectroscopy (Heia et al., 2007) are under continuous improvement processes.

Regardless of the inspection method employed, when facing up to an infected fish lot, correction measures settled at any step or procedure will depend on how relevant the parasite infection is. In other words, the Hazard Analysis and Critical Control Points (HACCP) works in an overall predictive assessment fashion that should include the parasite identity, the spread of parasites in the edible part of fish, and the food quality and safety implications of this biological hazard. This study was intended to help express and resolve all of these questions by designing a simple scoring system of parasite infection in fish flesh. In order to provide evidencebased criteria, we inspected and then scored several commercial frozen fish lots to offer a proof-of-concept of the applicability of the inspection system proposed.

\section{Materials and Methods}

\section{Parasite diagnosis}

As Regulation (EC) No. 2074/2005 specifies in Section 1 of Annex II, laying down specific provisions for visual inspection of eviscerated fish, fish fillets, and slices, a representative number of individuals will be submitted to a visual inspection at establishments on land and on board factory vessels. It also states that qualified technicians from establishments will determine the scale and frequency of inspections depending on the type of the fish products, their geographical origin, and the final use they are intended for. During the present work and as a proof-of-concept to demonstrate the feasibility of this scheme to be incorporated to routine quality control programs in fish industries, a total of 11 commercial lots, each one comprising 17-329 specimens of 10 fish species from three FAO fishing areas were sampled and characterized as summarized in Table 1. The whole musculature of each individual was inspected. Guts were not included in the examinations because these parts are usually discarded during fish-

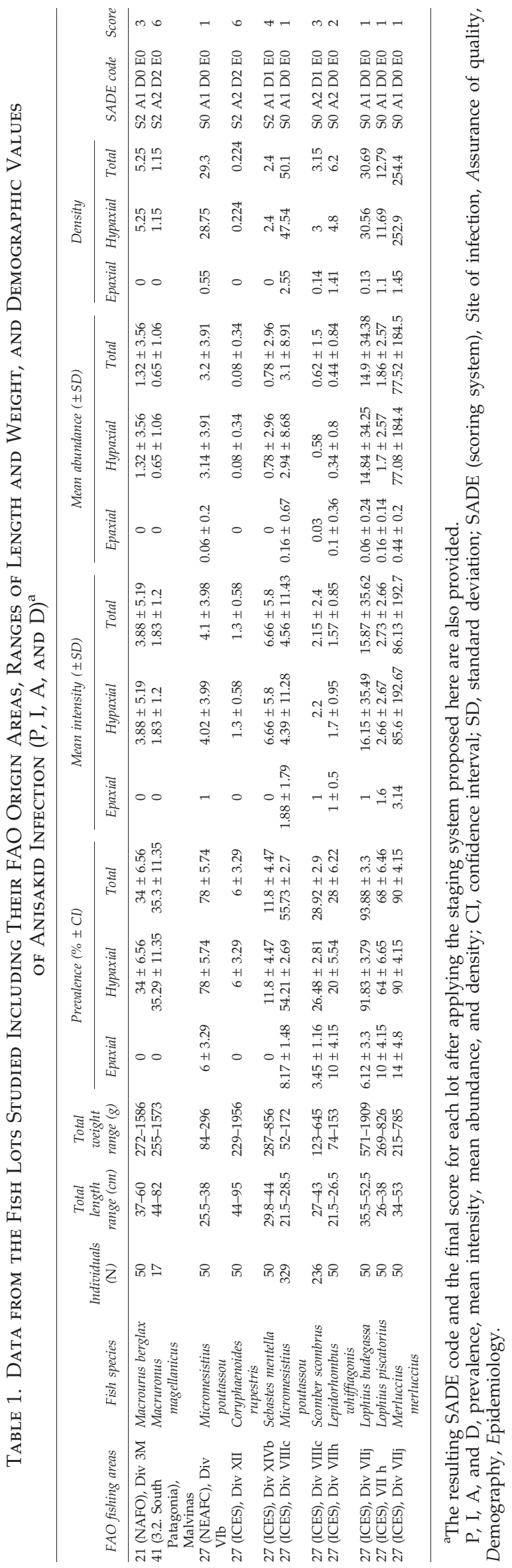




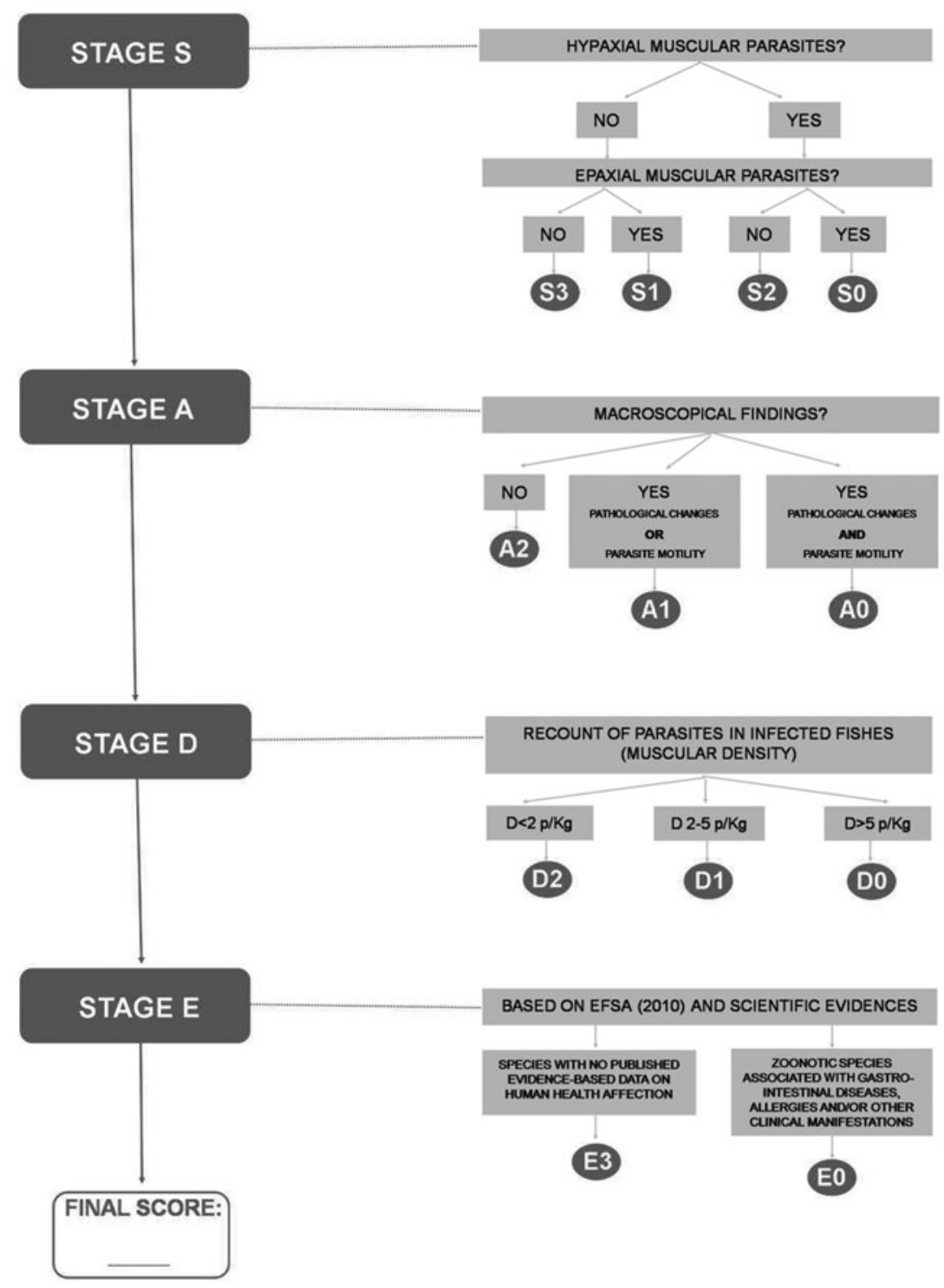

FIG. 1. Flow diagram for the Site of infection, Assurance of quality, Demography, Epidemiology (SADE) Scoring System illustrates an ordered and structured work schema based on Hazard Analysis and Critical Control Point principles to be easily implemented and followed by fish industries. From stage 1 to 4 , the user classifies each inspected fish lot according to the localization of parasites, the presence/absence of pathological or unaesthetic signs in the edible part of fishes, the density of infection, and finally to the epidemiological relevance of the etiologic agent. As result, a SADE code and a final score are obtained for each lot checked, in order to decide which industrial process or final destination may be followed.

processing procedures. At the time of capture, fishes were frozen at $-20^{\circ} \mathrm{C}$ in order to avoid migrations of anisakid larvae from visceral cavity to somatic muscle. Full necropsies, collection of parasites, and tissue sampling were carried out in every single fish. Then each fish was thinly sectioned and every fragment was visually inspected for parasites on a candling table with the aid of a Nikon SMZ800 stereomicroscope. Afterward, the whole fish muscle (hypaxial and epaxial regions separately) of each individual was digested in pepsin solution according to Llarena-Reino et al. (2013) to recover previously undetected parasites during the visual inspection. Any parasite found was identified on the basis of morpho- anatomical diagnostic characters (Berland, 1961, 1989; Fagerholm, 1982; Olson et al., 1983; Smith, 1983; Køie, 1993). Moreover, for some specimens molecular identification was performed by amplification and sequencing of the ITS1-rDNA region, using the primers NC5-NC2 (Zhu et al., 1998). DNA extraction of nematodes was carried out with NucleoSpin Tissue Kit (Macherey-Nagel). PCR reactions were performed in a total volume of $25 \mu \mathrm{L}$ containing $1 \mu \mathrm{L}$ of genomic DNA (150-200 ng), PCR buffer at $1 \times$ concentration, $1.5 \mathrm{mM} \mathrm{MgCl}_{2}$, $0.2 \mathrm{mM}$ nucleotides (Roche Applied Science), $0.3 \mu \mathrm{M}$ primers, and $0.625 \mathrm{U}$ Taq DNA polymerase (Roche Applied Science). The cycling program was $2 \mathrm{~min}$ at $94^{\circ} \mathrm{C}, 35$ cycles of $30 \mathrm{~s}$ at 
Table 2. Fish Species Studied, Including the Total Number of Individuals Dissected $(N)$, Showing Total Muscular Parasitized Fishes from Each lot and the Individuals That Were Selected for Parasite Sequencing, Total Muscular Larvae Found in the Selected Fishes and the Site of Infection in the Hosts, and Anisakids (Species and Number) Diagnosed After Sequencing and Their Corresponding ACCESSION Numbers From GenBANK

\begin{tabular}{|c|c|c|c|c|c|c|c|}
\hline \multirow[b]{2}{*}{ Fish species (N) } & \multirow{2}{*}{$\begin{array}{c}\text { Parasitized } \\
\text { hosts/selected hosts } \\
\text { for parasite } \\
\text { sequencing }\end{array}$} & \multirow{2}{*}{$\begin{array}{c}\text { Total count } \\
\text { of parasites } \\
\text { in selected hosts }\end{array}$} & \multicolumn{2}{|c|}{$\begin{array}{l}\text { Host-site of } \\
\text { infection }\end{array}$} & \multirow{2}{*}{$\begin{array}{c}\text { Parasites } \\
\text { successfully } \\
\text { sequenced }\end{array}$} & \multirow{2}{*}{$\begin{array}{c}\text { Etiologic agents } \\
\text { (parasite species } \\
\text { diagnosed and } \\
\text { number) }\end{array}$} & \multirow{2}{*}{$\begin{array}{c}\text { GenBank } \\
\text { accession number }\end{array}$} \\
\hline & & & Hypaxial & Epaxial & & & \\
\hline $\begin{array}{l}\text { Macrourus } \\
\quad \text { berglax (50) }\end{array}$ & $20 / 10$ & 43 & 43 & 0 & 11 & $\begin{array}{l}\text { Anisakis simplex } \\
\text { sensu stricto (11) }\end{array}$ & KF51289 - KF512839 \\
\hline $\begin{array}{l}\text { Macruronus } \\
\text { magellanicus } \\
\text { (17) }\end{array}$ & $16 / 2$ & 5 & 5 & 0 & 2 & Anisakis pegreffii (2) & KF512840, KF512841 \\
\hline $\begin{array}{l}\text { Micromesistius } \\
\text { poutassou } \\
\text { NEAFC (50) }\end{array}$ & $41 / 9$ & 74 & 72 & 2 & 9 & $\begin{array}{l}\text { Anisakis simplex } \\
\text { sensu stricto (9) }\end{array}$ & KF512842 - KF512850 \\
\hline $\begin{array}{l}\text { Coryphaenoides } \\
\text { rupestris (50) }\end{array}$ & $6 / 1$ & 1 & 1 & 0 & 1 & $\begin{array}{l}\text { Anisakis simplex } \\
\text { sensu stricto (1) }\end{array}$ & KF512857 \\
\hline $\begin{array}{l}\text { Sebastes mentella } \\
\quad(50)\end{array}$ & $29 / 3$ & 59 & 59 & 0 & 3 & $\begin{array}{l}\text { Anisakis simplex } \\
\text { sensu stricto (3) }\end{array}$ & KF512858 - KF512860 \\
\hline $\begin{array}{l}\text { Micromesistius } \\
\text { poutassou }\end{array}$ & $271 / 10$ & 60 & 49 & 11 & 10 & $\begin{array}{l}\text { Anisakis simplex } \\
\text { sensu stricto (4) }\end{array}$ & KF512861 - KF512864 \\
\hline ICES (329) & & & & & & Anisakis pegreffii (6) & KF512851 - KF512856 \\
\hline \multirow[t]{2}{*}{$\begin{array}{l}\text { Scomber } \\
\quad \text { scombrus (236) }\end{array}$} & $84 / 2$ & 4 & 4 & 0 & 3 & $\begin{array}{l}\text { Anisakis simplex } \\
\text { sensu stricto (1) }\end{array}$ & KF512865 \\
\hline & & & & & & $\begin{array}{l}\text { Pseudoterranova } \\
\text { sp. (2) }\end{array}$ & KF512907, KF512908 \\
\hline $\begin{array}{l}\text { Lepidorhombus } \\
\text { whiffiagonis } \\
\text { (50) }\end{array}$ & $18 / 3$ & 6 & 4 & 2 & 3 & $\begin{array}{l}\text { Anisakis simplex } \\
\text { sensu stricto (3) }\end{array}$ & KF512866 - KF512868 \\
\hline \multirow[t]{2}{*}{$\begin{array}{l}\text { Lophius } \\
\quad \text { budegassa (50) }\end{array}$} & $46 / 14$ & 557 & 539 & 18 & 15 & $\begin{array}{l}\text { Anisakis simplex } \\
\text { sensu stricto (12) }\end{array}$ & KF512869 - KF512880 \\
\hline & & & & & & $\begin{array}{l}\text { Pseudoterranova } \\
\quad \text { sp. (3) }\end{array}$ & KF512909 - KF512911 \\
\hline $\begin{array}{l}\text { Lophius } \\
\text { piscatorius } \\
(50)\end{array}$ & $36 / 10$ & 52 & 52 & 0 & 10 & $\begin{array}{l}\text { Anisakis simplex } \\
\text { sensu stricto (10) }\end{array}$ & KF512881 - KF512890 \\
\hline \multirow{2}{*}{$\begin{array}{l}\text { Merluccius } \\
\quad \text { merluccius } \\
\quad(50)\end{array}$} & $45 / 15$ & 1994 & 1970 & 24 & 18 & $\begin{array}{l}\text { Anisakis simplex } \\
\text { sensu stricto (16) }\end{array}$ & \\
\hline & & & & & & $\begin{array}{l}\text { Pseudoterranova } \\
\quad \text { sp. (2) }\end{array}$ & KF512912, KF512913 \\
\hline
\end{tabular}

NEAFC, North East Atlantic Fisheries Commission; ICES, International Council for the Exploration of the Sea.

$94^{\circ} \mathrm{C}, 30 \mathrm{~s}$ at $55^{\circ} \mathrm{C}$, and $75 \mathrm{~s}$ at $72^{\circ} \mathrm{C}$, followed by $7 \mathrm{~min}$ at $72^{\circ} \mathrm{C}$. PCR products were separated on a $1 \%$ agarose (in $1 \times$ Trisacetic EDTA buffer) gel, stained with ethidium bromide, and scanned in a GelDoc XR documentation system (Bio-Rad Laboratories). PCR products were purified with MinElute PCR Purification Kit (Qiagen GmbH, Hiden, Germany). Sequencing was performed by Secugen Company (Madrid, Spain). The chromatograms were analyzed using ChromasPro v.1.41 (Technelysium Pty Ltd.). Sequences were subject to Basic Local Alignment Search Tool (BLAST) analyses against available sequences from GenBank, through web servers of the National Center for Biotechnology Information (USA).

The terms prevalence $(\mathrm{P})$, mean intensity (I), mean abundance (A), and density (D) of infection were determined for each fish lot following Bush et al. (1997) and Rózsa et al. (2000).

\section{Scoring system}

The scoring system, namely SADE (Site of infection, Assurance of quality, Demography, Epidemiology), presents a cate- gorization of parasite infection. This tool is being presented in a highly visual and rapid-reference format. Fish lots are grouped according to four homogeneous categories (indices or "bins" of disease importance, namely $S, A, D$, and $E$ ), which are further divided with some accommodation into subcategories (denoted by numerals). The lower the number, the more advanced the hazard (i.e., "high-risk features") tends to be. The objective of SADE is the score of fish lots. By summing the numerical values assigned to each batch along the four categories, the SADE system adopts a 10-point scale. Each company must determine the level of score that sets off the implementation of measures to ensure food safety and quality of processed batches. The highest score indicates parasite-free fish lots. The lowest scores refer to serious weaknesses in the fish evaluated; that means a fish lot that should be reprocessed to guarantee its visual quality and/or safety attributes.

- Site of infection (the $S$ category assesses the anatomic exposure of fish flesh recorded at inspection).

S0: disseminated (spread throughout the whole flesh) 

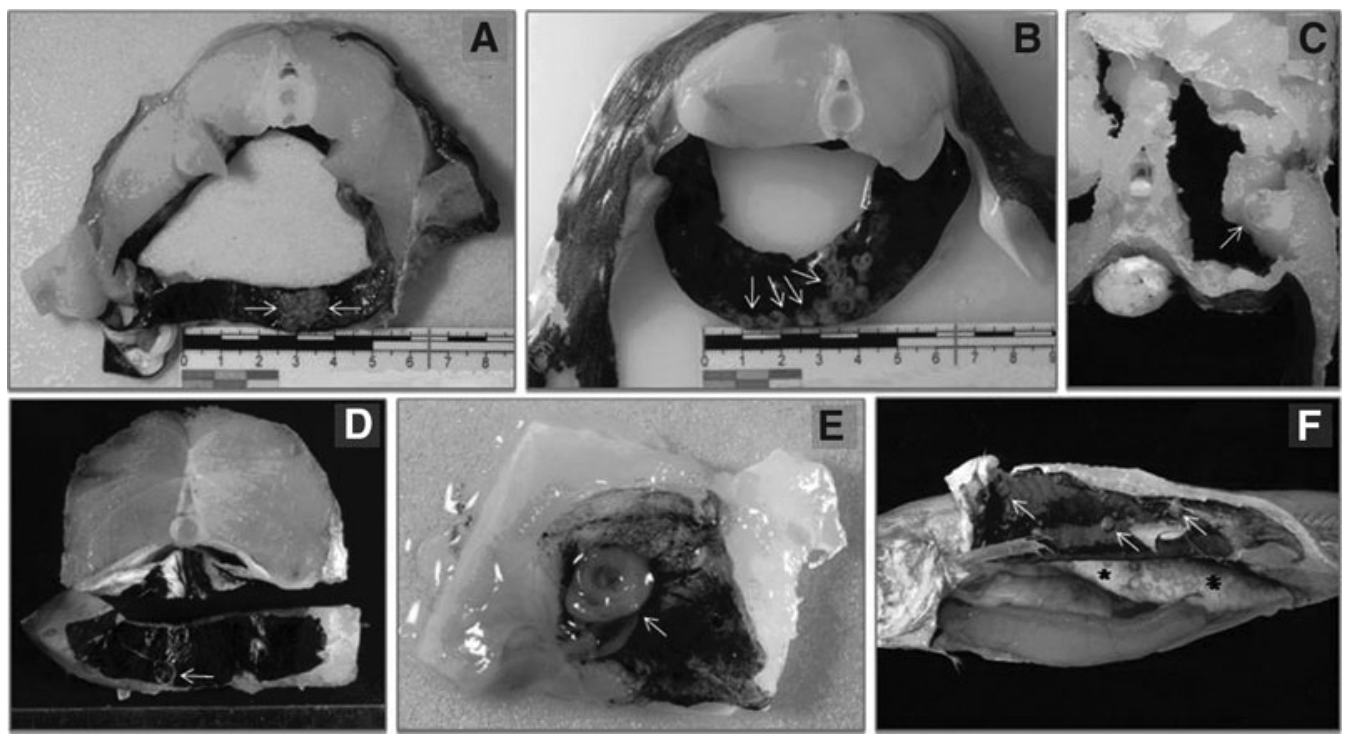

FIG. 2. Transversal sections of Lophius budegassa (A, B), Macrourus berglax (C), Merluccius merluccius (D), Sebastes mentella (E), and an individual of Micromesistius poutassou (F) showing higher amounts of anisakids at the hypaxial region than at the epaxial musculature. Parasites are located encysted inside the belly flaps and muscle, as well as covering them. F also shows a high quantity of embedded worms in some internal organs such as the liver (black asterisks). White arrows: Anisakid larvae.

S1: located in the epaxial zone

S2: located in the hypaxial zone, including the visceral body cavity

S3: parasite-free

- Assurance of quality: macroscopic pathological-unaesthetic commercial findings (the A category shows whether there are manufacturing and/or visual parasite problems reported at line or on site in contaminated fish lots).

A0: both topics included in A1 (pathological changes and parasite motility)

A1: gross pathological changes in infected tissues (undesirable components such as nodules in bellyflaps, melanized capsules in fillets, milky flesh, hemorrhages in the vent areas (e.g., Beck et al., 2008) or commercial reject due to a live parasite, mostly associated with parasite motility in fresh fish (e.g., Pascual et al., 2010)

A2: neither pathological nor commercial problems

- Demography of infection (the $\mathbf{D}$ category assesses the quantity of infection recorded at inspection, upon adapted and combined criteria based on CODEX STAN 165 [1989], CODEX STAN 190 [1995], CX/FFP 08/29/7, and on Wooten and Cann [2001]).

D0: density $>5$ parasites $/ \mathrm{kg}$

D1: density $2-5$ parasites $/ \mathrm{kg}$

D2: density $<2$ parasites $/ \mathrm{kg}$

- Epidemiological relevance of the species (the $E$ category describes the risk of the hazard after parasite species diagnoses, based on EFSA opinion and previous clinical evidences, already cited).

E0: zoonotic species of parasite (or its metabolites) associated with gastrointestinal diseases, other documented allergies, and/or clinical manifestations

E3: species of parasite with no published evidencebased data demonstrating human health affection. The importance of this point in terms of food security leads to assigning it a value of 3 points

\section{Flow diagram: An easy tool to use the scoring system}

Based on the SADE scoring system and following an HACCP schema, the flow diagram herein proposed was subsequently generated to standardize epidemiological stages provided by fish-inspection results. Figure 1 illustrates this flow diagram as a user-friendly tool that can be easily implemented and controlled by the technicians and followed by fish workers.

\section{Results}

\section{Parasite diagnosis}

Table 1 gathers the characteristics of all the processed fish lots. Three nematode species belonging to Anisakis and Pseudoterranova genera were identified by molecular studies as responsible for muscular infection in the fish lots analyzed (Table 2). For every fish species, demography of infection showed higher values at the hypaxial region than in the epaxial muscle (Fig. 2). In fact, over $45 \%$ of the inspected lots were parasite free at the epaxial muscle, whereas all the lots showed some degree of infection at the belly-flap region surrounding the viscera (hypaxial region). Anisakid parasites were never exclusively found in epaxial flesh. Although these results showed that epaxial infection always took place simultaneously with hypaxial location and not vice versa (this may be related to migration routes from viscera to muscle), some authors have demonstrated that there is a positive relationship between the gut and muscular number of parasites at epaxial musculature as well (Llarena et al., 2012). Because of this, epaxial infection has to be taken into account during fish inspection processes. On the other hand, demographic values of parasite infection were the highest (from high to low) in Lophius budegassa, Merluccius merluccius, Micromesistius poutassou, and Lophius piscatorius. Coryphaenoides rupestris showed the lowest anisakid infection values. No fish species were found to be free of parasites. 


\section{Fitting the scoring system}

Results based on epidemiological relevance of the parasite, pathological findings, and demographic values of infection for each fish lot fit easily into the scoring strategy. Table 1 reports the inspection results categorized by the SADE scoring system, thus showing for each fish species a "SADE Score" as results of the addition of the code points. For example, Merluccius merluccius from FAO 27 has a scoring of 1 , which results after adding up the scoring in each code ("S0 A1 D0 E0"). The score refers to a fish lot with a disseminated Anisakis infection, which could produce gastrointestinal diseases, allergies, and/or other clinical manifestations for the consumer, relevant commercial repercussions (due to evident pathological signs in the infected areas), and density values of infection greater than five parasites per kilogram.

Regarding the resulting scores, all of the species had between 1 and 6 points, and FAO 27 species (except for Coryphaenoides rupestris and Sebastes mentella) were the lowest scoring species. It also was remarkable that the two lots whose fishes showed the largest body lengths (belonging to Coryphaenoides rupestris and Macruronus magellanicus, from higher to lower) were the groups with the highest resulting scores.

\section{Discussion}

Currently, the European fish industry complies with the current legislation, recommended practices, and guidelines implemented by the governments and regulatory agencies, to carry out parasite control on their facilities and products. Basically, official inspections and self-management programs based on the HACCP system comprise the current practices to eliminate or reduce the risk of this biological hazard in seafood products. Despite this, there is still a historical concern regarding consumer complaints or lawsuits in trade operations when a contaminated fish lot reaches any given susceptible step from the sea to the plate. These problems arise above all due to the absence of an established legal maximum limit for anisakids in fish lots. Specifically, Regulation EC $178 / 2002$ states that food shall not be placed on the market if it is unsafe (i.e., injurious to health or unfit for human consumption). Regardless of the treatments that could be applied on parasitized fishes to prevent the ingestion of viable parasites (i.e, zoonoses), any parasitized fish is unfit for reasons of contamination by extraneous matter or otherwise. Moreover, the subjective application of some confusing concepts such as "visible parasite" and "clearly contaminated," specified in the European Hygiene Package (2004), Council Regulation (EC) 2406/96, and Commission Regulations (EC) 1662-1664/ 2006, makes it possible that each operator follows its own rules. In fact, the absence of a criterion standard method and the lack of an analytical critical limit to distinguish an acceptable from an unacceptable infected fish lot provoke a heterogeneous modus operandi at self-management controls. This circumstance leads to multiple methods of managing parasitized fish lots and does not prevent rejections in the last points of fish value chain due to visually highly parasitized fish. This is the reason why in the absence of an inspection standard and a quantum satis statement for parasites, it is important that fish industries embrace a common language to operate (i.e., standard terminology) that guarantees inspectors and consumers an appropriate predictive scoring of parasitized fish.
SADE scores can be fitted to any commercial fish lot from a particular fishing ground, size-maturity-age of fish, fish cohort, or postharvest condition. This information could then be used to propose risk mitigation and prevention measures at harvesting, processing, and postprocessing. Moreover, SADE scoring is an added-value tool that improve the modus operandi at self-management processes by increasing (1) consumer, professional, and trade confidence (due to a standardized working method); and (2) competitive strengthening in fish operators by achieving a higher standard quality and preventing product losses. In fact, SADE may accurately predict outcomes for the fishery industries related to the unaesthetic images that significantly impact on the commercial value of the affected products. This fact has been forcing the seafood industry to discard large quantities of fish and to intensify quality-inspection protocols on seafood products.

Thereafter, the SADE scoring system can be adapted or modified as needed over time. The SADE lexicon could be multifold by adding variables (i.e., diagnostic factors) into subcategories. This illustrates the future increasing complexity of stage grouping, when factors other than S, A, D, and E, such as branches and leaves, are included and added to the main tree trunk. SADE was constructed to assess four basic indicative categories, but this nodal staging system can be adapted to build more "look-up" predictive classifications in other well-known muscular parasites in seafood products. Therefore, scoring would give a common language for evaluating parasite risk in fish inspections, becoming a technological tool operating in silico for research, industrial, and commercial use within HACCP programs. Scoring is also useful in harmonization and prospection of research results derived from large data sets and from the peer-reviewed literature (e.g., meta-analysis). In this way, the SADE system has been constructed as a "bin model." That means that it can use the diagnosis of an infected fish lot already in the bin (i.e., in a given subcategory) to predict what will happen to a new fish lot placed in that bin.

\section{Acknowledgments}

We would like to thank the excellent technical assistance from the Ecobiomar staff. Xunta de Galicia has funded this work under Projects INCITE-07MMA015CT, IN841C, 10TAL001CT, and 10TAL033E. María Llarena-Reino thanks Fundação para a Ciência e a Tecnologia for financial support under Grant SFRH/BD/45398/2008.

\section{Disclosure Statement}

No competing financial interests exist.

\section{References}

Abe N, Ohya N, Yanagiguchi R. Molecular characterization of Anisakis pegreffii larvae in Pacific cod in Japan. J Helminthol 2005;79:303-306.

Abollo E, Gestal C, Pascual S. Anisakis infestation in marine fish and cephalopods from Galicia Waters: An update perspective. Parasitol Res 2001;87:492-499.

Adams AM, Miller KS, Wekell MM, Dong FM. Survival of Anisakis simplex in microwave-processed arrow tooth flounder (Atheresthes stomias). J Food Prot 1999;62:403-409.

Adams AM, Murrell KD, Ross JH. Parasites of fish and risks to public health. Rev Sci Technol 1997;16:652-660. 
Audicana MT, Ansotegui IJ, Fernández de Corres L, Kennedy MW. Anisakis simplex: Dangerous dead and alive? Trends Parasitol 2002;18:20-25.

Beck M, Evans R, Feist SW, Stebbing P, Longshaw M, Harris E. Anisakis simplex sensu lato associated with red vent syndrome in wild adult Atlantic salmon Salmo salar in England and Wales. Dis Aquat Org 2008;82:61-65.

Berland B. Nematodes from some Norwegian marine fishes. Sarsia 1961;2:1-50.

Berland B. Identification of larval nematodes from fish. Nematode problems in North Atlantic fish. Möller H. (ed.). Report from a workshop in Kiel 3-4 April 1989. International Council for the Exploration of the Sea CM/F, 6, 1989.

Bush AO, Lafferty KD, Lotz JM, Shostak AW. Parasitology meets ecology on its own terms: Margolis et al. revisited. J Parasitol 1997;83:575-583.

Butt AA, Aldridge KE, Sander CV. Infections related to the ingestion of seafood. Part II: parasitic infections and food safety. Lancet Infect Dis 2004;4:294-300.

Chen Q, Yu HQ, Lun ZR, Chen XG, Song HQ, Lin RQ, Zhu XQ. Specific PCR assays for the identification of common anisakid nematodes with zoonotic potential. Parasitol Res 2008;104: 79-84.

Choudhury GS, Bublitz CG. Electromagnetic method for detection of parasites in fish. J Aquat Food Prod Tech 1994;3:49-64.

[Codex] Codex Alimentarius. Codex standard for quick frozen blocks of fish fillet, minced fish flesh and mixtures of fillets and minced fish flesh. CODEX STAN 165-1989. Rev. 1-1995. Norway, 1989:1-10.

[Codex] Codex Alimentarius. Codex general standard for quick frozen fish fillets. CODEX STAN 190-1995. Norway, 1995:1-6.

Commission Regulation (EC) No 1662/2006 of 6 November 2006 amending Regulation (EC) No. 853/2004, Regulation (EC) No. 1663/2006 amending Regulation (EC) No. 854/2004, Regulation (EC) No. 1664/2006 amending Regulation (EC) No 2074/ 2005. Off J Eur Union 18.11.2006;320:1-10.

Commission Regulation (EC) No. 2074/2005 of 5 December 2005 laying down implementing measures for certain products under Regulation (EC) No. 853/2004, Regulation (EC) No. 854/ 2004, and Regulation (EC) No. 882/2004, derogating from Regulation (EC) No. 852/2004 and amending Regulations (EC) No. 853/2004 and (EC) No. 854/2004. Off J Eur Union 22.12.2005;338:27-59.

Council Regulation (EC) No. 2406/96 of 26 November 1996 laying down common marketing standards for certain fishery products. Council of the European Union. Luxembourg, OJ L 23.12.1996;334:1-24.

CX/FFP 08/29/7. Proposed Draft Standard for Smoked Fish, Smoked-Flavoured Fish and Smoked-Dried Fish. Joint FAO/ WHO Food Standards Programme CODEX Committee on fish and fishery products, 29th Session. Trondheim, Norway, 1823 February 2008.

Dick TA, Dixon BR, Choudhury A. Diphyllobothrium, Anisakis and other fish-borne parasitic zoonoses. Southeast Asian J Trop Med Public Health 1991;22(Suppl):150-152.

[EFSA] European Food Safety Authority. Scientific Opinion on risk assessment of parasites in fishery products. EFSA Panel on Biological Hazards (BIOHAZ). EFSA J 2010;8:1543.

European Hygiene Package Regulation (EC) 852/2004 on the hygiene of foodstuffs; Regulation (EC) 853/2004 laying down specific hygiene rules for food of animal origin and Regulation (EC) 854/2004 laying down specific rules for the organization of official controls on products of animal origin intended for human consumption. Commission to the Council and the
European Parliament. Luxembourg, OJ L 30.04.2004;139:1320

Fagerholm HP. Parasites of fish in Finland. IV Nematodes. Act Acad Ab 1982;40:1-128.

Fang W, Liu F, Zhang S, Lin J, Xu S, Luo D. Anisakis pegreffii: A quantitative fluorescence PCR assay for detection in situ. Exp Parasitol 2011;127:587-592.

Hafsteinsson H, Parker K, Chivers R, Rizvi SSH. Application of ultrasonic waves to detect sealworms in fish tissue. J Food Sci 1989;54:244-247.

Hartmann F, Klaus M. Apparatus for handling fish fillets for the purpose of quality inspection. US Patent. Patent Number: 4,744,131. 1988.

Heia K, Sivertsen AH, Stormo SK, Elvevoll E, Wold JP, Nilsen H. Detection of nematodes in cod (Gadus morhua) fillets by imaging spectroscopy. J Food Sci 2007;72:E011-E015.

Herrero B, Vieites JM, Espiñeira M. Detection of anisakids in fish and seafood products by real-time PCR. Food Control 2010;22:933-939.

Holst JC, Nielsen F, Hodneland K, Nylund A. Observations on the biology and parasites of postsmolt Atlantic salmon, Salmo salar, from the Norwegian Sea. J Fish Biol 1993;42:962-966.

Intapan PM, Thanchomnang T, Lulitanond V, Phongsaskulchoti $\mathrm{P}$, Maleewong W. Real-time fluorescence resonance energy transfer PCR with melting curve analysis for the detection of Opisthorchis viverrini in fish intermediate hosts. Vet Parasitol 2008;157:65-71.

Jenks WG, Bublitz CG, Choudhury GS, Ma YP, Wikswo JP Jr. Detection of parasites in fish by superconducting quantum interference device magnetometry. J Food Sci 1996;61:865-869.

Køie M. Nematode parasites in teleosts from 0 to $1540 \mathrm{~m}$ depth off the Faroe Islands (the North Atlantic). Ophelia 1993;38:217-243.

Levsen A, Lunestad BT, Berland B. Low detection efficiency of candling as a commonly recommended inspection method for nematode larvae in the flesh of pelagic fish. J Food Prot 2005;68:828-832.

Llarena-Reino M, González ÁF, Vello C, Outeiriño L, Pascual S. The accuracy of visual inspection for preventing risk of Anisakis spp. infection in unprocessed fish. Food Control 2012;23:54-58.

Llarena-Reino M, Piñeiro C, Antonio J, Outeiriño L, Vello C, González ÁF, Pascual S. Optimization of the pepsin digestion method for anisakids inspection in the fishing industry. Vet Parasit 2013;191:276-283.

López I, Pardo MA. A phage display system for the identification of novel Anisakis simplex antigens. J Immunol Methods 2011;373:247-251.

Lunestad BT. Absence of nematodes in farmed Atlantic salmon (Salmo salar) in Norway. J Food Prot 2003;66:122-124.

Lysne DA, Hemmingsen W, Skorping A. Pepsin digestion reveals both previous and present infections of metacercariae in the skin of fish. Fish Res 1995;24:173-177.

Marty GD. Anisakid larva in the viscera of a farmed Atlantic salmon (Salmo salar). Aquaculture 2008;279:209-210.

McClelland G, Misra RK, Martell DJ. Variations in abundance of larval anisakines, sealworm (Pseudoterranova decipiens) and related species, in eastern Canadian cod and flatfish. Can Tech Rep Fish Aquatic Sci 1985;1392, 57pp.

Monis PT, Giglio S, Keegan AR, Thompson RCA. Emerging technologies for the detection and genetic characterization of protozoan parasites. Trends Parasitol 2005;21:340-346.

Nieuwenhuizen N, Lopata AL, Jeebhay MF, Herbert DR, Robin TG, Brombacher F. Exposure to the fish parasite Anisakis causes allergic airway hyperreactivity and dermatitis. J Allergy Clin Immunol 2006;117:1098-1105. 
Nilsen H, Heia K, Sivertsen A. Detection of parasites in fish: Developing an industrial solution. Infofish Int 2008;3:26-35.

Olson AC, Lewis MD Jr, Hauser ML. Proper identification of anisakine worms. Am J Med Technol 1983;49:111-114.

Pascual S, Antonio J, Cabo ML, Piñeiro C. Anisakis survival in refrigerated fish products under $\mathrm{CO} 2$ modified-atmosphere. Food Control 2010;21:1254-1256.

Plessis K, Lopata AL, Steinman H. Adverse reactions to fish. Curr Allergy Clin Immunol 2004;17:4-8.

Pontes T, D'Amelio S, Costa G, Paggi L. Molecular characterization of larval anisakid nematodes from marine fishes of Madeira by a PCR-based approach, with evidence for a new species. J Parasitol 2005;91:1430-1434.

Regulation (EC) No. 178/2002 of the European Parliament and of the Council of 28 January 2002, laying down the general principles and requirements of food law, establishing the European Food Safety Authority and laying down procedures in matters of food safety. OJ L 1.2.2002;31:1-24.

Rello FJ, Adroher FJ, Benítez R, Valero A. The fishing area as a possible indicator of the infection by anisakids in anchovies (Engraulis encrasicolus) from southwestern Europe. Int J Food Microbiol 2009;129:277-281.

Rijpstra AC, Canning EU, Van Ketel RJ, Eeftinck Schattenkerk JKM, Laarman JJ. Use of light microscopy to diagnose smallintestinal microsporidiosis in patients with AIDS. J Infect Dis 1988;157:827-831.

Rodríguez-Mahillo AI, González-Muñoz M, de las Heras C, Tejada M, Moneo I. Quantification of Anisakis simplex allergens in fresh, long-term frozen, and cooked fish muscle. Foodborne Pathog Dis 2010;7:967-973.

Rózsa L, Reiczigel J, Majoros G. Quantifying parasites in samples of hosts. J Parasitol 2000;86:228-232.

Smith JW. Anisakis simplex (Rudolphi, 1809, det. Krabbe, 1878) (Nematoda: Ascaridoidea): Morphology and morphometry of larvae from euphausiids and fish, and a review of the lifehistory and ecology. J Helmintol 1983;57:205-224.

Smith JW. Larval ascaridoid nematodes in myopsid and oegopsid cephalopods from around Scotland and in the northern North Sea. J Mar Biol Assoc 1984;UK64:563-572.

Smith JW, Wootten R. Anisakis and anisakiasis. Adv Parasit 1978;16:93-163.

Smith JW, Wootten R. Recent surveys of larval anisakine nematodes in gadoids from Scottish Waters. International Council for the Exploration of the Sea. Sea Mammal Research Unit. Copenhagen 1979; CM/G:46 (8 pp.)
Stromnes E, Andersen K. Distribution of whaleworm (Anisakis simplex, Nematoda, Ascaridoidea) L3 larvae in three species of marine fish; saithe (Pollachius virens (L.)), cod (Gadus morhua (L.)) and redfish (Sebastes marinus (L.)) from Norwegian waters. Parasitol Res 1998;84:281-285.

Thien PC, Dalsgaard A, Thanh BN, Olsen A, Murrell KD. Prevalence of fishborne zoonotic parasites in important cultured fish species in the Mekong Delta, Vietnam. Parasitol Res 2007;101:1277-1284.

Thu ND, Dalsgaard A, Loan LTT, Murrell KD. Survey for zoonotic liver and intestinal trematode metacercariae in cultured and wild fish in An Giang Province, Vietnam. Korean J Parasitol 2007;45:45-54.

Vidacek S, de las Heras C, Tejada M. Quality of fish muscle infested with Anisakis simplex. Food Sci Technol Int 2009;15:283-290.

Wharton DA, Hassall ML, Aalders O. Anisakis (Nematoda) in some New Zealand inshore fish. New Zeal J Mar Fresh 1999;33:643-648.

Wold JP, Westad F, Heia K. Detection of parasites in cod fillets by using SIMCA classification in multispectral images in the visible and NIR region. Appl Spectrosc 2001;55:1025-1034.

Wooten R, Cann DC. Round worms in fish. Ministry of Agriculture, Fisheries and Food. Torry Research Station, Aberdeen. Torry Advisory Note 2001, No. 80, 5 pp.

Xu X, Sui J, Cao L, Lin H. Direct competitive enzyme-linked immunosorbent assay (ELISA) for rapid screening of anisakid larvae in seafood. J Sci Food Agric 2010;90:877-881.

Zhu XQ, D'amelio S, Palm HW, Paggi L, George-Nascimento M, Gasser RB. SSCP-based identification of members within the Pseudoterranova decipiens complex (Nematoda: Ascaridoidea: Anisakidae) using genetic markers in the internal transcribed spacers of ribosomal DNA. Parasitology 2002;124:615-623.

Zhu XQ, Gasser RB, Podolska M, Chilton NB. Characterisation of anisakid nematodes with zoonotic potential by nuclear ribosomal DNA sequences. Int J Parasitol 1998;28:1911-1921.

Address correspondence to: María Llarena-Reino, DVM Ecobiomar Instituto de Investigaciones Marinas de Vigo Consejo Superior de Investigaciones Científicas (CSIC) Eduardo Cabello 6 36208 Bouzas-Vigo, Spain

E-mail: mariallarena@iim.csic.es 